\title{
Atmospheric and oceanic dust fluxes in the northeastern tropical Atlantic Ocean: how close a coupling?
}

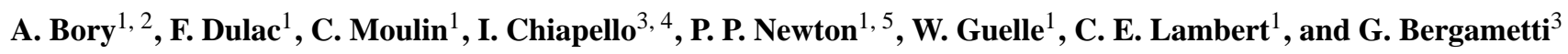 \\ ${ }^{1}$ Laboratoire des Sciences du Climat et de l'Environnement, 91198 Gif-sur-Yvette, France \\ ${ }^{2}$ Lamont-Doherty Earth Observatory of Columbia University, Palisades, NY 10964, USA \\ ${ }^{3}$ Laboratoire Inter-Universitaire des Systèmes Atmosphériques, Faculté des Sciences et Technologies, 94010 Créteil, France \\ ${ }^{4}$ Laboratoire d'Optique Atmosphérique, Université des Sciences et Technologies de Lille 59655 Villeneuve d'Ascq Cedex, \\ France \\ ${ }^{5}$ School of Biological and Molecular Sciences, Oxford Brookes University, Headington, Oxford OX3 0BP, UK
}

Received: 14 November 2001 - Revised: 10 June 2002 - Accepted: 2 July 2002

\begin{abstract}
Atmospheric inputs to the ocean of dust originating from Africa are compared with downward dust flux in the oceanic water column. Atmospheric fluxes were estimated using remote-sensing-derived dust optical thickness and parameters from a transport/deposition model (TM2z). Oceanic fluxes were measured directly over/in two regions of contrasting primary productivity of the northeastern tropical Atlantic (one mesotrophic and one oligotrophic, located at about 500 and $1500 \mathrm{~km}$ off Mauritania) underlying the offshore dust plume. In both regions, estimates of annual atmospheric dust inputs to the ocean surface are lower than, but of the same order of magnitude as, oceanic fluxes $(49.5$ and $8.8 \mathrm{mg} \cdot \mathrm{m}^{-2} \cdot \mathrm{d}^{-1}$ in the mesotrophic and oligotrophic regions). Part of this mismatch may reflect both a general flaw in the dust grain size distribution used in transport models, which likely underestimates large particles, and/or lateral advection to each region of dustier surface waters from upstream, where dust deposition is higher. Higher-frequency temporal coupling between atmospheric and oceanic fluxes seems to be primary-productivity dependent, as hypothesized in previously reported studies.
\end{abstract}

Key words. Atmospheric composition and structure (aerosols and particles; geochemical cycles) Oceanography: biological and chemical (geochemistry)

\section{Introduction}

Wind-blown lithogenic dust could exert a strong climate forcing via radiative scattering and condensation processes while in the atmosphere (Levin et al., 1996; Tegen et al., 1997), and also via its role in oceanic processes, for example, through iron-fertilization (Falkowski, 1998). Yet the quantification of today's atmospheric dust cycle has remained largely elusive. In several regions, notably off northwest Africa, much of this dust settles to comprise the main source

Correspondence to: A. Bory (bory@1deo.columbia.edu) of lithogenic material to the ocean (Rea, 1994). However, direct measurements of dust deposition onto the ocean are scarce, and reliable estimates require continuous monitoring since only a few events may control the yearly flux (LoÿePilot et al., 1986; Prospero et al., 1987; Bergametti et al., 1989). Such measurements are not available for the eastern tropical Atlantic Ocean. Estimates of dust fluxes in this region, as well as on the global scale, have been obtained from atmospheric dust concentrations, settling rates and scavenging by precipitation (Duce et al., 1991; Prospero et al., 1996), and more recently from transport models (Mahowald et al., 1999; Guelle et al., 2000; Ginoux et al., 2001).

Atmospheric dust inputs to the ocean have also been indirectly assessed from accumulation rates in sediments, and from sediment traps in the water column. These ocean-based methods are generally used to validate model outputs, assuming a conservative dust transfer through the water column. Such an assumption may be confounded by, for example, advective processes (e.g. Ratmeyer et al., 1999a), and the variable efficiency of biologically-mediated downward dust transport (e.g. Bory and Newton, 2000). Due to the dearth of dust deposition measurements close to ocean time-series sites, only a few studies in the Mediterranean Sea have quantitatively explored the direct coupling of atmospheric dust deposition with fluxes in the water column (Buat-Ménard et al., 1989; Dulac et al., 1996). But results from these studies are somewhat tentative, given the rather short/fragmented time-series data in the water column.

Here we present a comparison between estimates of daily inputs of atmospheric dust to the ocean and downward lithogenic particle flux in the water column over an annual cycle, for two regions of contrasting primary productivity (i.e. biological activity) - mesotrophic and oligotrophic (hereinafter $\mathrm{M}$ and $\mathrm{O}$ ) - downstream of Africa in the northeastern subtropical Atlantic (Fig. 1). Atmospheric data result from a combination of satellite-derived observations of the dust load in the air column and model-derived deposition rates, and the oceanic data consists of time series mea- 


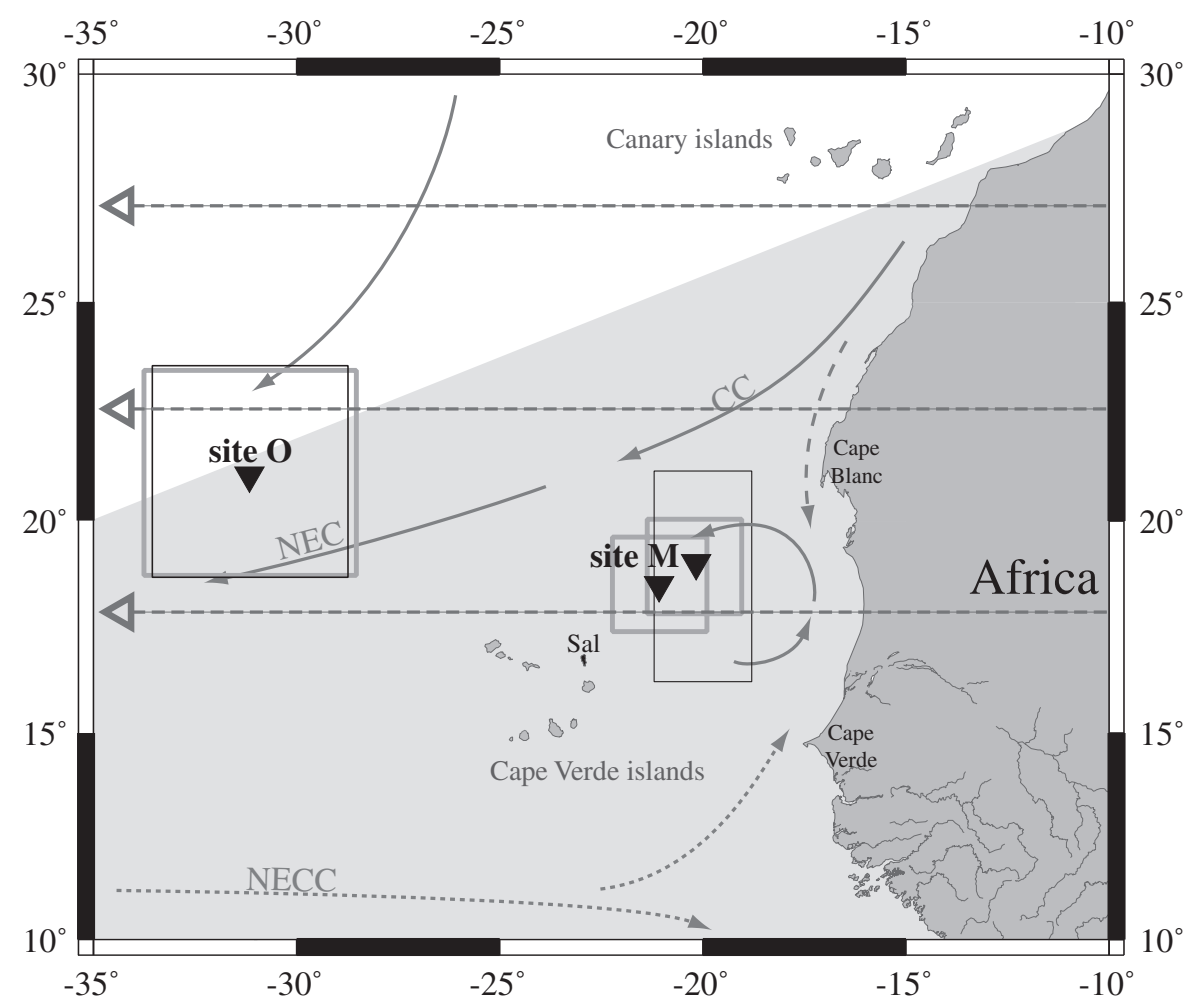

Fig. 1. Mooring locations (solid triangles), schematic near-surface circulation and atmospheric dust transport pathways. Abbreviations are $\mathrm{O}$, oligotrophic; M, mesotrophic; CC, Canary Current; NEC, North Equatorial Current; NECC, North Equatorial Counter Current. Solid arrows, currents: solid line, all year round; dashed line, fall, winter and spring only; dotted line, summer and fall only. Shaded area, winter atmospheric dust transport track. Open arrows, summer atmospheric dust transport direction. Rectangles: gray outline, Meteosat "windows"; black outline, TM $2 \mathrm{z}$ boxes. sured by sediment traps at several depths in the water column. Temporal matches and mismatches of the atmospheric and oceanic data sets are presented to complement previously published data (Bory and Newton, 2000) in terms of understanding the dust transfer processes from the atmosphere to the ocean water column, depending on the biological activity in the surface waters. Quantitatively, atmospheric and oceanic fluxes show significant discrepancies. The possible reasons for these are discussed in detail. Surface water circulation may play a role. However, general flaws in dust characteristic representation in transport models - grain size in particular - are likely to be responsible for at least part of the observed difference.

\section{Strategy}

\subsection{Oceanic flux}

Time-series measurements of particle fluxes down through the water column at three sites (Fig. 1) were obtained for periods of 9-15 months during 1990-92 at 10-28 day resolution using deep-moored conical sediment traps within the EUMELI (EUtrophe MEsotrophe oLIgotrophe) and BOFS (Biogeochemical Ocean Flux Studies) programs of the Joint Global Ocean Flux Study (Bory and Newton, 2000). Fluxes were measured at 1000 and $2500 \mathrm{~m}$ depth at the oligotrophic and mesotrophic EUMELI sites $\left(21^{\circ} 03^{\prime} \mathrm{N}, 31^{\circ} 10 \mathrm{~W}\right.$ and $18^{\circ} 30^{\prime} \mathrm{N}, 21^{\circ} 05 \mathrm{~W}$ ), and at 1140 and $2190 \mathrm{~m}$ depth at the mesotrophic BOFS site $\left(19^{\circ} 00^{\prime} \mathrm{N}, 20^{\circ} 10 \mathrm{~W}\right)$. All moorings were equipped with current meters; detailed configuration, sampling and analytical procedures are described elsewhere (Bory and Newton, 2000). The lithogenic fraction of the total particle flux was estimated from $\mathrm{Al}$ concentration, assuming that lithogenic material is $8.4 \% \mathrm{Al}$ (value reported for deepsea sediment clay fraction by Turekian and Wedepohl, 1961).

\subsection{Atmospheric flux}

In the absence of direct measurements, atmospheric dust fallout to the ocean surface have been computed. State-of-the-art 3-D transport models of Saharan dust still show significant deficiencies in simulating dust deposition, even with the most thorough models such as the TM2z. This dust transport and deposition model has extensively been described and tested (Balkanski et al., 1996; Schulz et al., 1996; 1998; Guelle et al., 1998a, b; 2000). Briefly, this is a global 3D, off-line, tracer transport model with a grid size of $2.5 \mathrm{deg}$ and 9 sigma layers in the vertical $(959,894,797,635,470,323,202$, 110 and 40 mbar). It includes advection, convection, vertical diffusion, sub-grid scale vertical transport by turbulence and convection by clouds, sedimentation and a validated wet deposition scheme of dust particles. The dust size distribution is explicitly treated. The dust emissions are computed using a detailed prognostic parameterization which has been validated independently (Marticorena and Bergametti, 1995; Marticorena et al., 1997). The transport is driven by the 12-h analyzed meteorological fields for the European Centre for the Medium-range Weather Forecast (ECMWF) and run with a 1-h time step. Still, TM2z, which simulates par- 
Table 1. Summary of the TM2z-derived parameters used to estimate atmospheric dust fluxes to the ocean in region $\mathrm{O}$ and $\mathrm{M}$ (corresponding boxes on the model grid are shown in Fig. 1). Specific extinction cross section and dry deposition efficiencies retrieved from TM2z correspond to "winter" (December-April) rainless days (precipitation in TM2z are model outputs from the European Centre for Medium-Range Weather Forecast) when dust concentration was $>0.01 \mathrm{mg} \mathrm{m}^{-2}$ and dust transport occurred below $1.2 \mathrm{~km}$

\begin{tabular}{lcc}
\hline & Region $\mathrm{O}$ & Region $\mathrm{M}$ \\
\hline $\begin{array}{l}\text { Specific extinction cross section } \\
\text { at } 550 \mathrm{~nm}\left(\mathrm{~m}^{2} \mathrm{~g}^{-1}\right)\end{array}$ & 1.09 & 0.98 \\
$\begin{array}{l}\text { Dry deposition efficiency } \\
\text { (Winter only) }\end{array}$ & 0.10 & 0.23 \\
Wet deposition efficiencies & $\sigma=0.04, N=2167$ & $\sigma=0.16, N=399$ \\
Average & & \\
Maximum & 0.08 & 0.09 \\
\hline
\end{tabular}

ticle size distribution evolution during transport (with a distribution at the source close to that of the desert background aerosol model given by Shettle, 1984), dry and wet deposition, as well as dust columnar optical thickness, misses important events when day-by-day comparisons of dust deposition fluxes are compared to coincident observations (see Guelle et al., 2000, for details). Moreover, in summer, TM2z does not yet reproduce correctly the dust concentration profile above the Cape Verde region due to uncertainties in the dust source expression. High dust concentration in the first levels of the model, corresponding to the trade winds, is obtained, whereas the transport is known to take place mainly in the Saharan Air Layer (hereinafter SAL) above the trade wind inversion (they have a marine origin at this time of the year and relatively low dust concentration is seen at ground level; Chiapello et al., 1995). As the altitude of the dust transport strongly affects the gravitational deposition of the dust, modeled dry deposition in summer is, as a result, likely to contain large errors. Dust fluxes to the ocean can also be estimated with a better resolution using remote-sensing-derived dust optical thickness. Such an approach, which requires one to estimate dust grain size distribution, as well as dry and wet deposition coefficients, has shown encouraging results in the Mediterranean (Dulac et al., 1992b, 1996). In these studies the grain size distribution was the "desert background" given by Shettle (1984). The deposition coefficient ranges, however, were poorly constrained.

Here, we combined remote-sensing-derived dust optical thickness obtained from Meteosat visible-channel numerical counts (see Moulin et al., 1997a, b, for details) and parameters from the transport model $\mathrm{TM} 2 \mathrm{z}$, to obtain the best possible estimate of dust deposition fluxes at the two marine sites. Over each mooring site, $\mathrm{M}$ and $\mathrm{O}$, the calculation of daily-averaged dust optical thickness was confined to a "window" of pixels (Fig. 1) enclosing the statistical catchment area of the deepest sediment trap (i.e. the area of the ocean surface within which the trap is supposedly collecting particles; Bory and Newton, 2000). Optical thickness was vertically resolved into low and high atmospheric levels (dry deposition is predominantly from lower levels). To achieve this resolution, for each dust "event" (a day when the optical thickness was above the monthly mean and exceeds that of the two preceding and following days), the altitude of the dust was assessed by back-trajectory analyses of air masses. These analyses were carried out using TM2z in reverse mode (and were, therefore, based on ECMWF wind field analyses; Ramonet et al., 1996) for two levels of the atmosphere above the mooring sites, one representing the trade wind (0.4-1.2 km altitude) and the other the Saharan Air Layer (hereinafter SAL; $2.6-4.7 \mathrm{~km}$ altitude), both of which are well documented in terms of dust transport. During a winter dust transport episode, for instance, Dulac et al. (2001), using a balloon borne nephelometer, observed that most of the dust was found between 600 and $1400 \mathrm{~m}$ altitude, just above the marine boundary layer, and in the summer, aircraft (Carlson and Prospero, 1972) and lidar (Karyampudi et al., 1999) observations showed that the SAL is located between 1.5 and $5-6 \mathrm{~km}$ altitude. For a given dust event, a continental origin of the air mass in the lower level and a marine origin in the upper level indicated that dust transport occurred in the trade winds, while the reverse indicated transport in the SAL. This approach clearly reproduces the seasonal cycle of dust transport in this region, with higher concentrations at the ground/sea level between early November and mid-April (Chiapello et al., 1995) driven by the continental trade winds (i.e. the "Harmattan"). This method's validity was further tested in region M (Fig. 1) for 1992, using measurements of daily atmospheric dust concentrations at the ground level on the nearby island of Sal in the Cape Verde Archipelago: measured peaks are in excellent agreement with optical-depthderived dust events identified in the lower atmosphere over region $\mathrm{M}$ using back-trajectories (Fig. 2).

In both $\mathrm{M}$ and $\mathrm{O}$ regions, calculations of atmospheric dust fluxes to the ocean surface were based on a summer/winter differentiation. For "winter" dust events (dust transport dominantly in the lower atmosphere), dry and wet depositions were taken into account. For "summer" dust events (dust transport predominately at altitude), dry deposition was con- 
$\begin{array}{ll}\text { Site M } & \text { Sal Island }\end{array}$

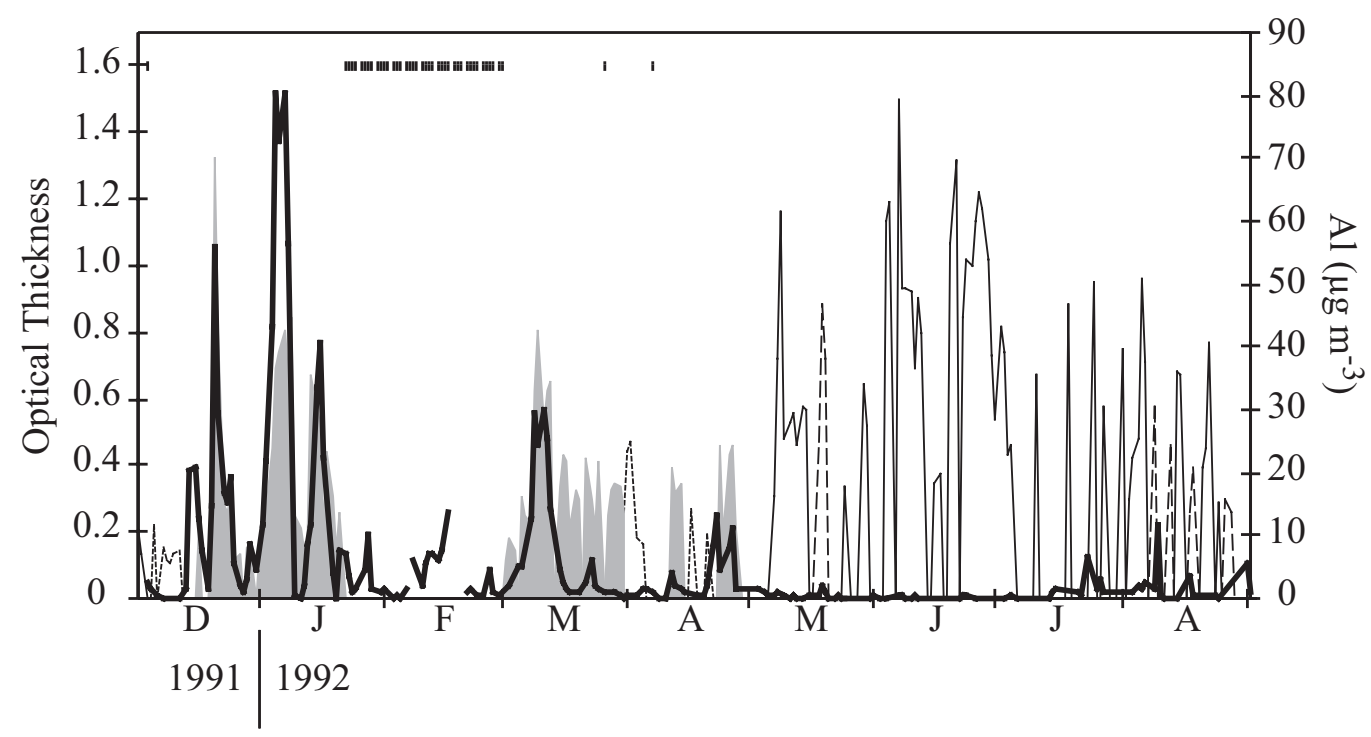

Fig. 2. Dust optical thickness at site $\mathrm{M}$ (shaded area and thin black lines) and dust concentration (expressed as $\mathrm{Al}$ ) in the air at ground level at Sal Island (bold solid black line) between December 1991 and August 1992. Shaded area, back trajectories indicate a continental origin of the air mass in the lower atmospheric level $(0.4-1.2 \mathrm{~km})$ and a marine origin in the upper level $(2.6-4.7 \mathrm{~km})$; thin solid black line, reverse situation; dotted line, no continental origin at any of the two levels; dotted line, continental origin at both atmospheric levels. Vertical bars indicate days for which no dust optical thickness data is available.

sidered negligible (see Fig. 2 and Chiapello et al., 1995). For each site, daily atmospheric dust columnar content was estimated using a specific extinction cross section calculated as the mean ratio of the dust optical thickness versus the atmospheric dust columnar content, both retrieved from TM2z (Table 1). As the model satisfactorily reproduces the dust concentration and vertical distribution in winter, daily dry deposition fluxes were then determined for this period using mean dry deposition efficiencies (ratio of the dry deposition flux versus dust columnar content) given by the model (Table 1). Daily wet deposition fluxes were determined all year round (the inaccuracy of the dust concentration profile in summer is thought to have little effect on the wet deposition efficiency) using the model daily wet deposition efficiencies (ratio of the wet deposition flux versus dust columnar content). When both dry and wet deposition occur, only the highest is taken into account.

\section{Results and discussion}

\subsection{Dry versus wet dust deposition}

In each region, both dry and wet deposition contribute significantly to the atmospheric-ocean dust flux (Table 2). Wet contribution to the total deposition, however, is much less than in the west tropical Atlantic (Prospero et al., 1987). This is consistent with the fact that (1) grain size distribution shifts towards smaller sizes as the distance from the source increases, and (2) dust reaching the western Atlantic is transported in the SAL at high altitude. Both factors limit the gravitational deposition of the long-range transported dust, which is, therefore, largely scavenged by rain, while coarser grain size and lower transport in the trade winds associated with little precipitation allow for dry deposition to dominate in the eastern Atlantic. Wet deposition occurs only in summer in region $\mathrm{M}$, but all year round in region $\mathrm{O}$. Most of the dust deposition takes place during a few major events, notably in region $\mathrm{M}$, where three dust events in winter and three in summer (Fig. 3a) - each about 4-15 days long - comprise about two-thirds of the dry and wet deposition, respectively (see Table 3 for details).

\subsection{Temporal variability of atmospheric and oceanic dust} fluxes

In region $\mathrm{M}$, the atmospheric deposition time series is characterized by a large flux increase in mid-December/earlyJanuary (Fig. 3a). Dust flux is then relatively low until August/September, apart from a large deposition in March/April. In the underlying water column, the highest lithogenic flux is observed at the beginning of the year (Fig. 3c), only a few weeks after the large winter atmospheric deposition event (Fig. 3a). The lithogenic flux then decreases progressively, perhaps showing two minor increases in spring and summer which coincide with large organic matter fluxes (Fig. 3b), and another increase (lower trap only) at the end of the time series (late August-early September 1991). The apparent similarities in the atmospheric dust and oceanic lithogenic time series at site M support Bory and Newton's (2000) conclusions that a rapid down-column transfer of the 


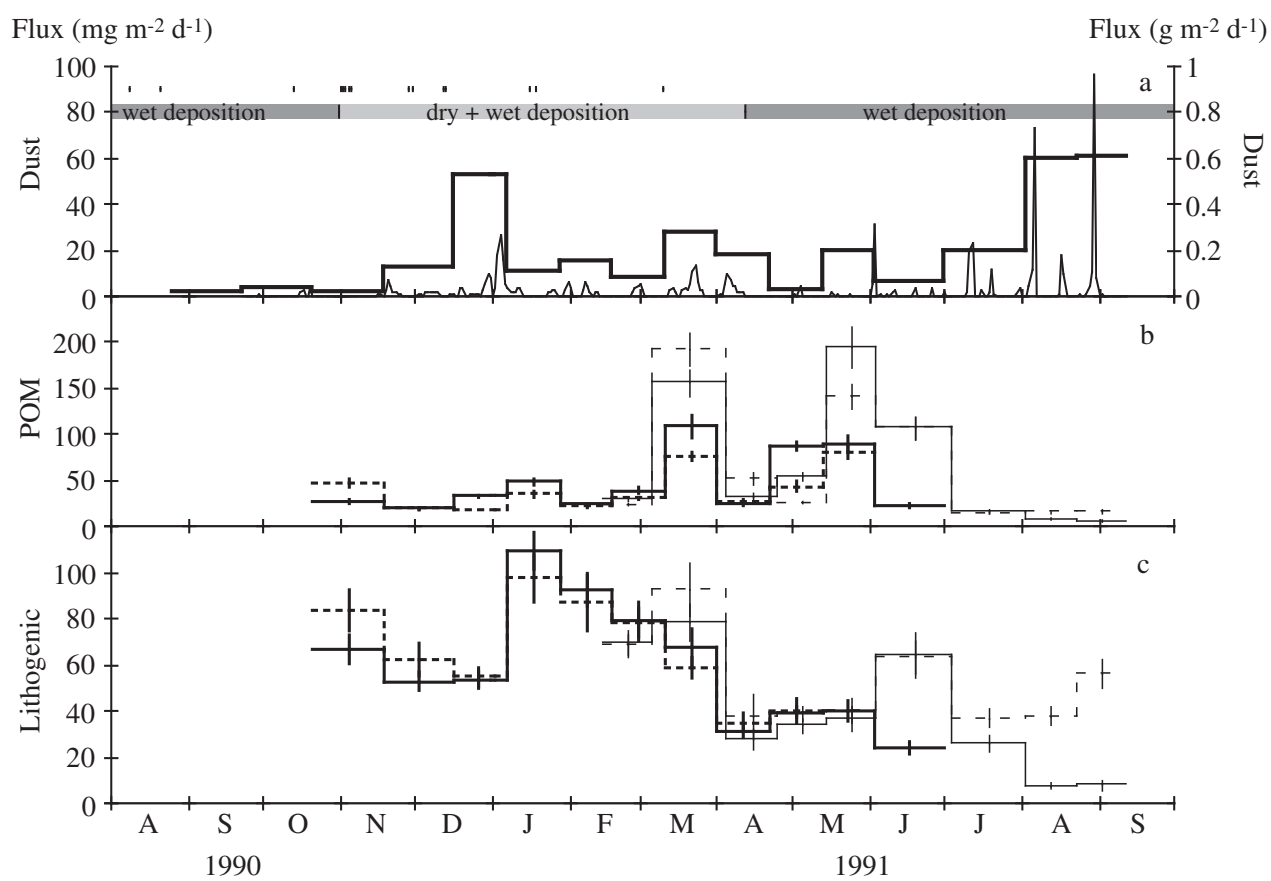

Fig. 3. Region M. (a) Atmospheric dust fluxes. Daily values (right-hand axis), and averages over sediment-trap sampling intervals (left-hand axis). As dust optical thickness obtained for both mooring-site "windows" (Fig. 1) were nearly identical, only results for the EUMELI site were used. Vertical bars indicate days for which no dust optical thickness data is available. (b) Particulate organic matter (POM) and (c) lithogenic fluxes in the water column (from Bory and Newton, 2000). Plain (dotted) thick and thin lines; BOFS 1140(2190) m and Eumeli 1000(2500) m depth traps, respectively.

Table 2. Mean atmospheric dust deposition and oceanic water column lithogenic fluxes during study periods at regions $\mathrm{O}$ and $\mathrm{M}$. Water-column fluxes are those obtained at 1000 and $1140 \mathrm{~m}$ depth at EUMELI and BOFS sites, respectively

\begin{tabular}{|c|c|c|c|c|c|}
\hline \multicolumn{2}{|c|}{$\begin{array}{c}\text { Flux } \\
\mathrm{mg} \mathrm{m}^{-2} \mathrm{~d}^{-1}\end{array}$} & \multicolumn{2}{|c|}{$\begin{array}{c}\text { Region } \mathrm{O} \\
\text { EUMELI: } 21.03^{\circ} \mathrm{N}-31.10^{\circ} \mathrm{W}\end{array}$} & \multicolumn{2}{|c|}{$\begin{array}{c}\text { Region } \mathrm{M} \\
\text { EUMELI: } 18.30^{\circ} \mathrm{N}-21.05^{\circ} \mathrm{W} \\
\text { BOFS: } 19.00^{\circ} \mathrm{N}-20.10^{\circ} \mathrm{W}\end{array}$} \\
\hline \multicolumn{6}{|c|}{ Atmosphere } \\
\hline Dust & & Winter & Summer & Winter & Summer \\
\hline & Dry deposition & 3.7 & - & 19.7 & - \\
\hline & Wet deposition & 1.3 & 1.0 & 0 & 22.6 \\
\hline & Mean & \multicolumn{2}{|c|}{3.6} & \multicolumn{2}{|c|}{21.1} \\
\hline & Prospero et al. (1996) & \multicolumn{2}{|c|}{$2.3 \mathrm{a}$} & \multicolumn{2}{|c|}{$16.0 \mathrm{~b}$} \\
\hline \multicolumn{6}{|c|}{$\underline{\text { Ocean water column }}$} \\
\hline Lithogenic & & \multicolumn{2}{|c|}{$8.8 \pm 1.1$} & \multicolumn{2}{|c|}{$49.5 \pm 4.7$} \\
\hline
\end{tabular}

${ }^{a}$ Value given for $20 / 30^{\circ} \mathrm{N}-30 / 40^{\circ} \mathrm{W}$.

$b$ Value given for $10 / 20^{\circ} \mathrm{N}-20 / 30^{\circ} \mathrm{W}$.

lithogenic material takes place, likely to be driven, as shown by these authors, by the high biological activity in surface waters and the consequent large and fast downward export of particulate organic material carrying the dust.

In region $\mathrm{O}$, most of the atmospheric dust deposition occurs over the fall-spring period (Fig. 4a). In the water column, lithogenic fluxes show no marked seasonal variability, but are generally higher in fall-spring than spring-summer
(Fig. 4c). Low-frequency variability in atmospheric dust deposition may, therefore, be reflected by water-column fluxes to some degree, but high-frequency temporal variability of lithogenic flux in the water column does not appear to be closely coupled to atmospheric inputs. Instead, the highfrequency lithogenic flux variability resembles that of the particulate organic matter (Fig. 4b; the linear regression gives a correlation coefficient $r^{2}$ of 0.64$)$, which is argued else- 


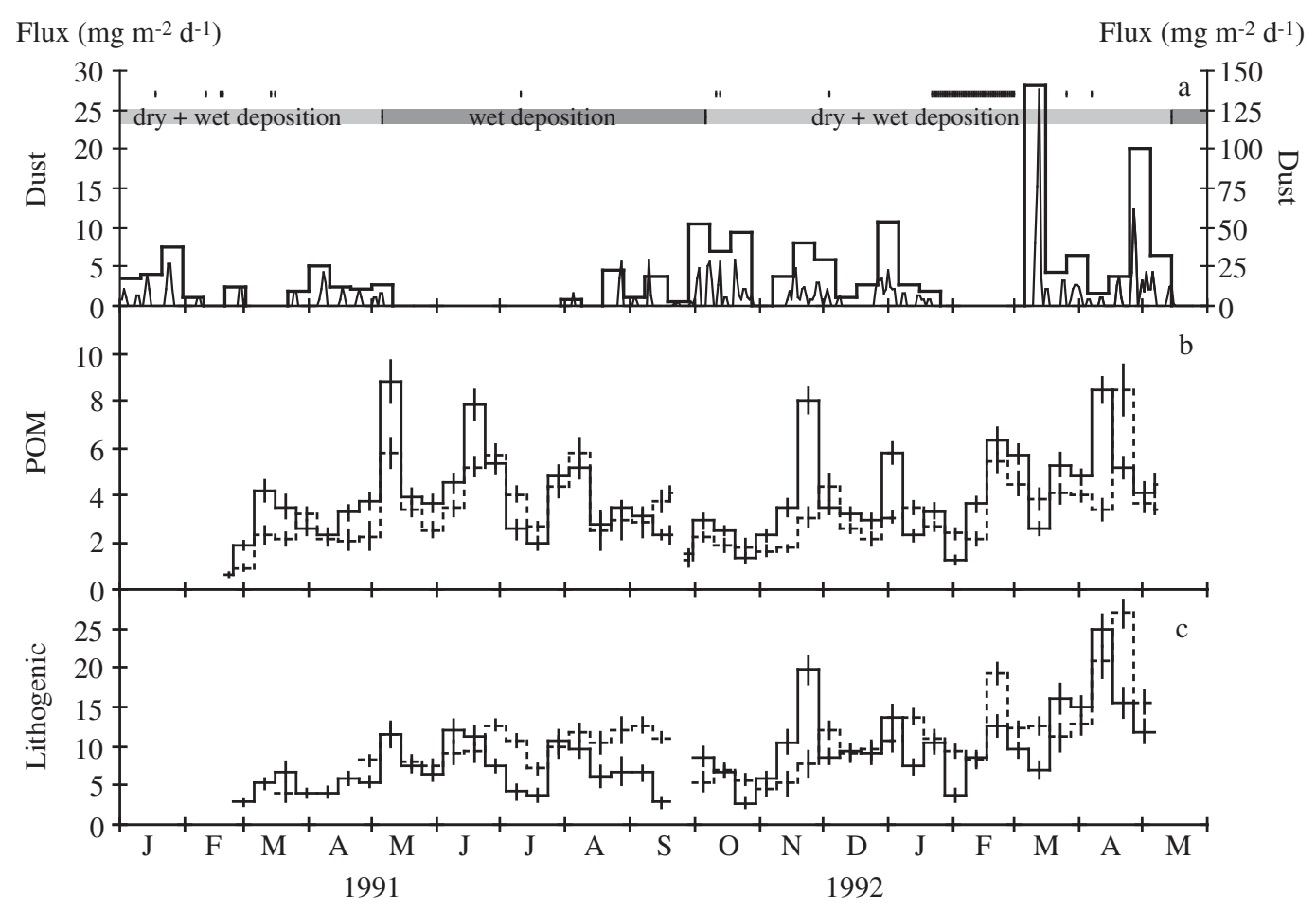

Fig. 4. Region O. As per Fig. 3 legend. (b), (c), Plain and dotted lines, Eumeli 1000 and 2500 m depth traps, respectively. Note that the time period and vertical scales are different from Fig. 3.

Table 3. Contribution of the 3 major dry and 3 major wet dust deposition events to the total dry/wet fluxes, respectively, estimated at site M during the study period

\begin{tabular}{lccccccc}
\hline & \multicolumn{3}{c}{ Dry deposition } & & \multicolumn{3}{c}{ Wet deposition } \\
\cline { 1 - 3 } \cline { 5 - 7 } Beginning of event & $27 / 12 / 90$ & $17 / 03 / 91$ & $01 / 04 / 91$ & & $01 / 06 / 91$ & $02 / 08 / 91$ & $26 / 08 / 91$ \\
Ending of event & $11 / 01 / 91$ & $25 / 03 / 91$ & $10 / 04 / 91$ & & $04 / 06 / 91$ & $05 / 08 / 91$ & $01 / 09 / 91$ \\
$\begin{array}{l}\text { Fraction of the total } \\
\text { dry/wet deposition }\end{array}$ & $35 \%$ & $16 \%$ & $12 \%$ & & $10 \%$ & $23 \%$ & $31 \%$ \\
\hline
\end{tabular}

where (Bory and Newton, 2000) to indicate that the latter limits the export of dust, and, therefore, controls its timing. Such a hypothesis was supported by particle settling rates and residence time measurements, that Bory and Newton (2000) found much slower and longer, respectively, in region $\mathrm{O}$ compared to $\mathrm{M}$. As a result, and in contrast with region $\mathrm{M}$, the oceanic time series at region $\mathrm{O}$ does not directly reflect the atmospheric signal.

3.3 Quantitative assessment of atmospheric and oceanic fluxes

Quantitatively, the downward atmospheric and oceanic dust fluxes are of the same order of magnitude, but the former are 2-3 times lower, on average (Table 2). There seem to be three possible causes for the mismatch: (i) down-column ocean fluxes of dust have been overestimated (sampling artifact or advected mid-water inputs of dust); (ii) atmospheric deposition has been underestimated; (iii) surface-water advection of deposited dust.

First, a possible overestimation of down-column ocean fluxes of dust due to a bias in sediment trap efficiency seems unlikely since the later has been assessed (Bory and Newton, 2000; Bory et al., 2001), and errors on the lithogenic flux are estimated at, on average, $<10 \%$. Moreover, the aluminum content value chosen to estimate dust flux is in the upper range of those given in the literature (see Prospero, 1996, for review). Significant mid-water lateral advection of resuspended bottom sediment to the traps is also improbable, given that no nepheloid layer was recorded and that the lithogenic flux varies little between different depths (Bory and Newton, 2000).

Concerning the second of the potential causes of the observed mismatch, a large underestimate of the summer atmospheric dust input to the ocean is not supported by the dust 
concentration time series over Sal (Chiapello et al., 1995). Although those concentration measurements do not capture the larger particles $(>20 \mu \mathrm{m})$ which may reach the region, those particles would represent at most $15 \%$ of the annual flux (Ratmeyer et al., 1999b) if we assume that sediment trap material grain size distribution reflects that of atmospheric dust in this range of the spectrum; this is an upper limit, although aggregation processes in the ocean, among other factors, may lead to overestimating large particles. Therefore, the 2-3-fold difference between atmospheric and oceanic fluxes cannot be attributed to our approximation of a negligible dry deposition in summer.

Ground-truthing indicates that remote measurements of dust optical depth are reliable (Moulin et al., 1997a), but converting dust optical depth to dust concentration using a constant factor incorrectly assumes that particle grain size distribution and density do not vary in time. It is difficult to assess precisely the influence of the density's potential variability but it is not thought to be significant considering the little temporal variation in the composition of the dust in that region (Glaccum and Prospero, 1978). The absolute value used in the model is 2.65 , which is in the high range of the density spectrum for atmospheric particles. Density could not, therefore, account for a possible underestimation of the atmospheric dust fluxes. Concerning the grain size distribution, the daily ratios of the atmospheric dust columnar content versus dust optical thickness given by the model vary only moderately, and there is no reason why the average values that are used for each site would lead to a systematic underestimation of dust concentration. Moreover, even if the value of the specific extinction cross section of the dust model at the source (about $0.8 \mathrm{~m}^{2} . \mathrm{g}^{-1}$; Moulin et al., 1997a, b) is used, the estimated atmospheric content and, therefore, deposition only increases by $\sim 20 \%$.

Dry deposition efficiencies depend on the square of the grain size, and are proportional to density, as well as the transport altitude. The relationship between the estimated dust concentration in the lower atmosphere and the dust concentration at ground level, as measured at Sal, appears to be variable (Fig. 2). This may reflect, among others, some variation in the altitude of transport which is beyond our analytical resolution. Since dry deposition depends on the altitude of the dust, the conversion of estimated dust concentration in the lower atmosphere to dry deposition, using a constant factor, is, therefore, an approximation, but here also, the associated uncertainties are unlikely to be systematic. In any case, in region $\mathrm{M}$, for instance, the dry deposition efficiency that would be required for mean atmospheric fluxes to match mean oceanic fluxes during the period when atmospheric transport occurs in the lower atmosphere is close to one, which is unrealistic.

Uncertainties associated with wet deposition also need to be considered, in particular in region $\mathrm{O}$, where precipitation is more abundant and where a wet deposition event can deliver up to $20 \%$ of the total dust deposition during the mooring deployment period. Such uncertainty is large due to uncertainties in ECMF modeled precipitation data, and also as the satellite sensor's ability to detect dust decreases with the cloud cover, which is when wet deposition is most likely to occur. However, considering the difference in precipitation occurrence in the two regions (none in region $\mathrm{M}$ during winter, according to ECMWF outputs, which is in agreement with precipitation data obtained at Sal Island; Bernadette Chatenet, personal communication, 1997), any associated dust-flux underestimation should not affect both sites similarly and could not explain the mismatch between atmospheric and oceanic data sets in winter at site $\mathrm{M}$, for instance.

Overall, although uncertainties associated with atmospheric dust flux are large, they do not seem to be able to explain on their own the systematic differences between atmospheric and oceanic fluxes in both regions, unless there is a significant bias in the modeled particle size distribution.

It is arguable, indeed, that a Shettle's desert backgroundlike distribution, such as the one used in the model, whose dust volume median diameter main mode (i.e. which represents nearly $80 \%$ of the total volume) is found at about $2.5 \mu \mathrm{m}$, represents the true dust distribution at the source, or even at the sampling sites $(<1000-3000 \mathrm{~km}$ away from the source), during dust outbreaks. Shettle's desert background distribution has been shown to represent well African dust over Corsica, matching the size distributions retrieved from cascade impactors in the $0.2-6 \mu \mathrm{m}$ size range (Dulac et al., 1989), and leading to satisfactory estimates of dust fluxes to the ocean in this region (Dulac et al., 1992b; 1996). Shettle's desert background distribution seems also to best simulate optical properties of the dust over the Atlantic (see Moulin et al., 2001, and references therein). However, particles with much larger grain size (whose contribution is generally difficult to assess quantitatively by cascade impactors) are observed near sources (e.g. Shettle, 1984), but also in remote areas (see Pye, 1987, for review). One of the most striking evidence of long-range transport of large particles is that of Betzer et al. (1988), who found particles up to $100 \mu \mathrm{m}$ in diameter thousands of kilometers from their source in the $\mathrm{Pa}$ cific Ocean. Microscope observations of Saharan dust gravitationally deposited in Corsica, for instance, have shown that particles over $10 \mu \mathrm{m}$ in diameter can control the dry deposition flux (Dulac et al., 1992a). The mass median diameter of particles in "red" rains collected in Europe is also found to be of the order of $10 \mu \mathrm{m}$ or more (Pitty, 1968; De Falco et al., 1996; Stefano Guerzoni, personal communication, 2001; François Dulac, unpublished data). A few quantitative grain size measurements are also available in the study region. Chester et al. (1971, 1972), for example, found that 75-91\% of dust collected in the eastern tropical Atlantic is $<4 \mu \mathrm{m}$. These measurements, however, were not taken following major dust storms. Prospero et al. (1970) report that coarser dust fall can occasionally occur, even reaching the western tropical Atlantic. As a result of a vigorous storm in June 1967, for instance, which was associated with a rapid transport across the Atlantic, these authors report that about half of the particles collected in Barbados was in the 5-20 $\mu \mathrm{m}$ fraction. It has to be pointed out, however, that these Atlantic studies were carried out using meshes, not filters, which may have 
introduced a bias (underestimation) at the small end of the grain size distribution. The above results, however, are consistent with airborne measurements in the summer of 1997 in the Canary Islands area which indicated that the size distribution in mass of the dust particles in the free troposphere was controlled by a mode at about $8 \mu \mathrm{m}$ in diameter (Collins et al., 2000).

No model to date is able to make these coarser particles travel very far, and shifting grain size distribution towards big particles in the model source actually reduces the long-range transport of these larger particles which fall even sooner (Schulz et al., 1998). Thus, although the grain size distribution computed by the model may represent satisfactorily the real size distribution of the dust most of the year, chances are that the latter could be greatly underestimated during major dust outbreaks affecting both atmospheric dust concentration, by underestimating the specific extinction cross section - values at $550 \mathrm{~nm}$ of about 0.55 and $0.7 \mathrm{~m}^{2} . \mathrm{g}^{-1}$ have been estimated in the Canaries (Maring et al., 2000) and Barbados (Li et al., 1996), and values even as low as $0.23 \mathrm{~m}^{2} . \mathrm{g}^{-1}$ have been proposed $2000 \mathrm{~km}$ away from the dust source (Schütz, 1979) - and the dry deposition efficiency calculations. As those outbreaks are responsible for a large fraction of the annual dust deposition, such a potential bias could indeed lead to a significant underestimation of the atmospheric dust flux, explaining in this study part and possibly most of the observed mismatch between atmospheric and oceanic dust fluxes. The likelihood of a significant underestimation of the contribution of large particles affecting primarily the dry deposition flux is supported by a recent study based on another transport model (Ginoux et al., 2001). In this study, unpredicted fluxes are thought to be due to the truncation of the larger size fraction contribution in the dust particle size range (largest simulated radius is $6 \mu \mathrm{m}$ ), yielding to as increased underestimation of deposition flux with decreasing distance to the source region.

The last hypothesis for this mismatch is surface-water advection of deposited dust. Surface currents have a strong westward component (Bory et al., 2001) that could deliver downstream the highly dust-enriched waters from coastal regions. If the atmospheric dust deposition gradient between regions $\mathrm{O}$ and $\mathrm{M}$ is extrapolated upstream, deposition near the coast is estimated to be 2-3 times larger than in region $\mathrm{M}$, consistent with the factors estimated using TM2z and the model of Prospero et al. (1996). Surface-water particulate aluminum (hereinafter $\mathrm{pAl}$ ) concentration measurements also show a steep gradient, about 5-fold between a site $130 \mathrm{~km}$ west of Cape Blanc and region M (Tachikawa et al., 1999). Given the surface currents in this region, typically $25-50 \mathrm{~cm} \mathrm{~s}^{-1}$, surface waters could be transported between these two sites in 8-16 days, which is the likely range for dust residence time in surface waters (Bory and Newton, 2000). Such a rapid westward transport is supported by pigment tracers and the timing of biogenic particle fluxes (Bory et al., 2001). Thus, the westward decreasing gradient in surface-water pAl concentration (also observed between regions $\mathrm{M}$ and $\mathrm{O}$ ) could also account for a significant part of the quantitative mismatch between mean dust deposition flux and water-column lithogenic flux for both regions $\mathrm{M}$ and O. Surface waters, acting as a westward conveyor belt, would transport deposited dust seaward, thus decoupling time-mean atmospheric deposition and water-column dust export in the space domain.

\section{Conclusions}

Quantifying the global dust cycle will only be achieved by modeling. In this effort, model outputs, dust deposition in particular, need to be tested against measured parameters in the field. Lithogenic fluxes in the ocean water column have recently been used on broad geographical scales to validate dust transport models (e.g. Mahowald et al., 1999), assuming a simplistic conservative transfer of the dust material from the atmosphere to the oceanic water column.

The study presented here aimed at comparing estimated dust deposition to the ocean and lithogenic fluxes in the water column at a high temporal resolution over a year-cycle period in the eastern tropical Atlantic, to document dust transfer processes from the atmosphere to the deep ocean and to test the validity of state-of-the-art dust transport model parameterization. This study was carried out in two contrasting regions in terms of biological activity, mesotrophic and oligotrophic, which was of particular interest given the major influence of the biological activity on the dust transfer throughout the water column. Comparing the best atmospheric dust deposition data set available (obtained using remote sensing derived data and parameters from the dust transport model $\mathrm{TM} 2 \mathrm{z}$ ) and lithogenic fluxes in the water column supports Bory and Newton's (2000) hypothesis that higher-frequency temporal coupling between atmospheric and oceanic fluxes seems to be primary-productivity dependent. Most importantly, this comparison shows that estimated atmospheric fluxes are 2-3 times lower that oceanic fluxes. A somewhat under-representation in dust transport models of large particles, which seem to have the potential for travelling much farther than models can predict, as well as a surface currents redistribution of dust before settling, appear to be the two likely causes for the apparent mismatch between dust flux estimates to the ocean and measured dust flux in the water column in the northeastern Atlantic. Estimating the respective contribution of the two identified causes is not possible here as the few evidences discussed indicate that each could have accounted for most of the mismatch.

Concerning the particle size distribution, a more elaborated way of representing particles shape (models incorrectly use the approximation of spherical and homogenous particles, while clay minerals generally produce flake-like particles; e.g. Bergametti et al., 1992) might help to improve the modeling of long-range transport of large particles. While accurate size distributions in the submicron and micron ranges are essential to radiative models, a better representation of larger particle modes would be crucial to the quantitative estimates of dust flux inputs to the ocean and 
associated iron fertilization estimates, for instance. Finally, when undertaking quantitative studies of dust cycling in regions with similar shallow ocean dynamics, including when attempting to validate model outputs, spatial decoupling of dust deposition and export by surface currents should be considered.

Acknowledgements. We are grateful to P. Bousquet and B. Aumont for help with back-trajectory calculations and presentation, respectively. We thank B. Chatenet for kindly providing us with Sal Island precipitation data. A. Bory thanks MENRT for studentship support, and P. Newton thanks BMS for a visiting research fellowship. LSCE contribution 776 and LDEO contribution 6337.

Topical Editor J.-P. Duvel thanks two referees for their help in evaluating this paper.

\section{References}

Balkanski, Y., Schultz, M., Marticorena, B., Bergametti, G., Guelle, W., Dulac, F., Moulin, C., and Lambert, C.: Importance of the source term and of the size distribution to model mineral dust cycle, in: The impact of desert dust from northern Africa across the Mediterranean, (Eds) Guerzoni, S., and Chester, R., Kluwer Academic Publishers, Oristano (Sardinia), pp. 69-76, 1996.

Bergametti, G., Dutot, A.-L., Buat-Ménard, P., Losno, R., and Remoudaki, E.: Seasonal variability of the elemental composition of atmospheric aerosol particles over the northwestern Mediterranean, Tellus, 41, 353-361, 1989.

Bergametti, G., Chapuis, A., Devaux, C., Druilhet, A., Fontan, J., Gaudichet, A., Gomes, L., Ide, H., Lamaud, E., Maidouka, A., and Tinga, A.: Atmosphere-soil exchange of mineral particles in a Sahelian area, in: Precipitation Scavenging and AtmosphereSurface Exchange, (Eds) Schwartz, S. E., and Slinn, W. G. N., Hemisphere, Richland, Wa, pp. 909-920, 1992.

Betzer, P. R., Carder, K. L., Duce, R. A., Merrill, J. T., Tindale, N. W., Uematsu, M., Costello, R. W., Young, R. W., Feely, R. A., Breland, J. A., Bernstein, R. E., and Greco, A. M.: Longrange transport of giant mineral aerosol particles, Nature, 336, 568571,1988

Bory, A. J.-M. and Newton, P. P.: Transport of airborne lithogenic material down through the water column in two contrasting regions of the eastern subtropical North Atlantic Ocean, Global Biogeochem. Cycles, 14, 297-315, 2000.

Bory, A., Jeandel, C., Leblond, N., Vangriesheim, A., Khripounoff, A., Beaufort, L., Rabouille, C., Nicolas, E., Tachikawa, K., Etcheber, H., and Buat-Ménard, P.: Particle flux within different productivity regimes off the Mauritanian upwelling zone (EUMELI program), Deep Sea Res. Part I, 48, 2251-2282, 2001.

Buat-Ménard, P., Davies, J. E., Remoudaki, E., Miquel, J.-C., Bergametti, G., Lambert, C. E., Ezat, U., Quétel, C., La Rosa, J., and Fowler, S. W.: Non-steady-state biological removal of the atmospheric particles from Mediterranean surface waters, Nature, 340, 131-133, 1989.

Carlson, T. N. and Prospero, J. M.: The large-scale movement of Saharan air outbreaks over the northern equatorial Atlantic, J. Appl. Meteorol., 11, 283-297, 1972.

Chester, R., Elderfield, H., and Griffin, J. J.: Dust transported in the North-east and South-east Trade Winds in the Atlantic Ocean, Nature, 233, 474-476, 1971.

Chester, R., Elderfield, H., Griffin, J. J., Johnson, L. R., and Padgham, R. C.: Eolian dust along the eastern margins of the Atlantic Ocean, Mar. Geol., 13, 91-106, 1972.
Chiapello, I., Bergametti, G., Gomes, L., and Chatenet, B.: An additional low layer transport of Sahelian and Saharan dust over the north-eastern tropical Atlantic, Geophys. Res. Lett., 22, 31913194, 1995.

Collins, D. R., Jonsson, H. H., Seinfeld, J. H., Flagan, R. C., Gasso, S., Hegg, D. A., Russel, P. B., Schmid, B., Livingston, J. M., Ostrom, E., Noone, K. J., Russell, L. M., and Putaud, J. P.: In situ aerosol-size distributions and clear-column radiative closure during ACE-2, Tellus, 52, 498-525, 2000.

De Falco, G., Molinaroli, E., and Rabitti, S.: Grain size analysis of aerosol and rain particles: a methodological comparison, in: The impact of desert dust from northern Africa across the Mediterranean, (Eds) Guerzoni, S., and Chester, R., Kluwer Academic Publishers, Oristano (Sardinia), 233-238, 1996.

Duce, R., Liss, P., Merrill, J., Atlas, E., Buat-Ménard, P., Hicks, B., Miller, J., Prospero, J., Arimoto, R., Church, T., Ellis, W., Galloway, J., Hansen, L., Jickells, T., Knap, A., Reinhardt, K., Schneider, B., Soudine, A., Tokos, J., Tsunogai, S., Wollast, R., and Zhou, M.: The atmospherical input of trace species to the world ocean, Global Biogeochem, Cycles, 5, 193-259, 1991.

Dulac, F., Buat-Ménard, P., Ezat, U., Melki, S., and Bergametti, G.: Atmospheric input of trace metals to the western Mediterranean: uncertainties in modelling dry deposition from cascade impactor data, Tellus, 41, 362-378, 1989.

Dulac, F., Bergametti, G., Losno, R., Remoudaki, E., Gomes, L., Ezat, U., and Buat-Ménard, P.: Dry deposition of mineral aerosol particles in the marine atmosphere: Significance of the large size fraction, in: Precipitation Scavenging and Atmosphere-Surface Exchange, (Eds) Schwartz, S. E., and Slinn, W. G. N., Hemisphere, Richland, Wa, pp. 841-854, 1992a.

Dulac, F., Tanré, D., Bergametti, G., Buat-Ménard, P., Desbois, M., and Sutton, D.: Assessment of the African Airborne Dust Mass Over the Western Mediterranean Sea Using Meteosat Data, J. Geophys. Res., 97, 2489-2506, 1992b.

Dulac, C., Moulin, C., Lambert, C. E., Guillard, F., Poitou, J., Guelle, W., Quetel, C. R., Schneider, X., and Ezat, U.: Quantitative remote sensing of African dust transport to the Mediterranean, in: The impact of desert dust from northern Africa across the Mediterranean, (Eds) Guerzoni, S., and Chester, R., Kluwer Academic Publishers, Oristano (Sardinia), pp. 25-49, 1996.

Dulac, F., Chazette, P., Gomes, L., Chatenet, B., Berger, H., and Vinicula Dos Santos, J. M.: Aerosol profiling of the lower troposphere off Sahara with coupled scatter and meteorological rawindsondes, J. Atmos. Sci., 32, 1069-1086, 2001.

Falkowski, P. G.: Evolution of the nitrogen cycle and its influence on the biological sequestration of $\mathrm{CO}_{2}$ in the ocean, Nature, 387 272-275, 1998.

Ginoux, P., Chin, M., Tegen, I., Prospero, J., Holben, B., Dubovik, O., and Lin, S.: Sources and distributions of dust aerosols simulated with the GOCART model, J. Geophys. Res., 106, 20255 $20273,2001$.

Glaccum, R. and Prospero, J.: Mineralogy and elemental composition of mineral aerosols over North-Atlantic Ocean, Transactions-AGU, 59(4), 283, 1978.

Guelle, W., Balkanski, Y. J., Dibb, J. E., Schulz, M., and Dulac, F.: Wet deposition in a global size-dependent aerosol transport model, 2. Influence of the scavenging scheme on $\mathrm{Pb}$ vertical profiles, surface concentrations and deposition, J. Geophys. Res., 103, 28 875-28 891, 1998a.

Guelle, W., Balkanski, Y. J., Schulz, M., Dulac, F., and Monfray, P.: Wet deposition in a global size-dependent aerosol transport 
model, 1. Comparison of a 1-year $210 \mathrm{~Pb}$ simulation with ground measurements, J. Geophys. Res., 103, 11 429-11 445, 1998 b.

Guelle, W., Balkanski, Y. J., Schulz, M., Marticorena, B., Bergametti, G., Moulin, C., Arimoto, R., and Perry, K. D.: Modeling the atmospheric distribution of mineral aerosol: Comparison with ground measurements and satellite observations for yearly and synoptic timescales over the North Atlantic, J. Geophys. Res., 105, 1997-2012, 2000.

Karyampudi, V. M., Palm, S. P., Reagen, J. A., Fang, H., Grant, W. B., Hoff, R. M., Moulin, C., Pierce, H. F., Torres, O., Browell, E. V., and Melfi, S. H.: Validation of the Saharan dust plume conceptual model using lidar, Meteosat, and ECMWF data, Bull. Am. Meteor. Soc., 80, 1045-4075, 1999.

Levin, Z., Ganor, E., and Gladstein, V.: The effects of desert particles coated with sulfate on rain formation in the eastern Mediterranean, J. Appl. Meteorol., 35, 1551-1523, 1996.

Li, X., Maring, H., Voss, K., and Prospero, J. M.: Dominance of mineral dust in aerosol light-scattering in the North Atlantic trade winds. Nature, 380, 416-419, 1996.

Loÿe-Pilot, M. D., J. M. Martin, and J. Morelli, Influence of Saharan dust on the rain acidity and atmospheric input to the Mediterranean, Nature, 321, 427-428, 1986.

Mahowald, N., Kohfeld, K., Hansson, M., Balkanski, Y., Harrison, S. P., Prentice, I. C., Schultz, M., and Rodhe, H.: Dust sources and deposition during the last glacial maximum and current climate: A comparison of model results with paleodata from ice cores and marine sediments, J. Geophys. Res., 104, 15 89515916, 1999.

Maring, H., Savoie, D., Izaguirre, M., McCormick, C., Arimoto, R., Prospero, J., and Pilinis, C.: Aerosol Physical and Optical Properties and their Relationship to Aerosol Composition in the Free Troposphere at Izaña, Tenerife, Canary Islands during July 1995, J. Geophys. Res., 105, 14 677-14 700, 2000.

Marticorena, B. and Bergametti, G.: Modeling the atmospherical dust cycle: 1. Design of a soil-derived dust emission scheme, J. Geophys. Res., 100, 16415-16430, 1995.

Marticorena, B., Bergametti, G., Aumont, B., Callot, Y., NDoume, C., and Legrand, M.: Modeling the atmospheric dust cycle. 2. Simulation of Saharan dust sources, J. Geophys. Res., 102, 4387-4404, 1997.

Moulin, C., Dulac, F., Lambert, C. E., Chazette, P., Jankowiac, I., Chatenet, B., and Lavenu, F.: Long-term daily monitoring of Saharan dust load over ocean using Meteosat ISCCP-B2 data 2. Accuracy of the method and validation using Sun photometer measurements, J. Geophys. Res., 102, 16 959-16 969, 1997a.

Moulin, C., Guillard, F., Dulac, F., and Lambert, C. E.: Long-term daily monitoring of Saharan dust load over marine areas using Meteosat ISCCP-B2 data, 1, Methodology and preliminary results for 1983-1994 in the Mediterranean, J. Geophys. Res., 102, 16947-16958, 1997b.

Moulin, C., Gordon, H. R., Banzon, V. F., and Evans, R. H.: Assessment of Saharan dust absorption in the visible from SeaWiFS imagery, J. Geophys. Res., 106, 18 239-18 250, 2001.

Pitty, A. F.: Particle size of the Saharan dust which fell in Britain in July 1968. Nature, 220, 364-365, 1968.

Prospero, J. M., Bonatti, E., Schubert, C., and Carlson, T. N.: Dust in the Caribbean atmosphere traced to an African dust storm, Earth Planet. Sci. Lett., 9, 287-293, 1970.

Prospero, J., Nees, R. T., and Uematsu, M.: Deposition rate of par- ticulate and dissolved aluminium derived from Saharan dust in precipitation at Miami, Florida, J. Geophys. Res., 92, 14723 14731, 1987.

Prospero, J. M.: The atmospheric transport of particles to the ocean, in: Particle Flux in the Ocean, (Eds) Ittekkot, V., Schäfer, P., Honjo, S., and Depetris, P. J., John Wiley, New York, pp. 19-52, 1996.

Prospero, J. M., Barrett, K., Church, T., Bentener, F., Duce, R. A., Galloway, J. N., Levy, II, H., Moody, J., and Quinn, P.: Atmospheric deposition of nutrients to the North Atlantic Basin, Biogeochemistry, 35, 27-73, 1996.

Pye, K.: Aeolian dust and dust deposits, Academic Press, London, 1987.

Ramonet, M., Le Roulley, J. C., Bousquet, P., and Monfray, P.: Radon-222 measurements during the Tropoz II campaign and comparison with a global atmospheric transport model, J. Atmos. Chem., 23, 107-136, 1996.

Ratmeyer, V., Fischer, G., and Wefer, G.: Lithogenic particle fluxes and grain size distributions in the deep ocean off NW Africa: Implications for seasonal changes of aeolian dust input and downward transport, Deep Sea Res. Part I, 46, 1289-1337, 1999a.

Ratmeyer, V., Balzer, W., Bergametti, G., Chiapello, I., Fischer, G., and Wyputta, U.: Impact of mineral dust on deep-ocean particle flux in the eastern subtropical Atlantic Ocean, Mar. Geol., 159, 241-252, 1999b.

Rea, D.: The paleoclimatic record provided by eolian deposition in the deep sea: The geologic history of wind, Rev. Geophys., 32, 159-195, 1994.

Schulz, M., Balkanski, Y., Guelle, W., Dulac, F., Moulin, C., and Lambert, C. E.: Relevant components to model the Saharan dust plume pattern over the Mediterranean Sea, in: The impact of desert dust from northern Africa across the Mediterranean, (Eds) Guerzoni, S., and Chester, R., Kluwer Academic Publishers, Oristano (Sardinia), pp. 51-58, 1996.

Schulz, M., Balkanski, Y., Guelle, W., and Dulac, F.: Role of aerosol size distribution and source location in a threedimensional simulation of a Saharan dust episode tested against satellite-derived optical thickness, J. Geophys. Res., 103, 10 579-10 592, 1998.

Schütz, L.: Saharan dust transport over the North Atlantic Ocean - Model calculations and measurements, in: Saharan dust (Mobilization, Transport, Deposition), (Ed) Morales, C., John Wiley \& Sons, Chichester-New York-Brisbane-Toronto, pp. 267-277, 1979.

Shettle, E. P.: Optical and radiative properties of a desert aerosol model, in: Proc. symposium on radiation in the atmosphere, (Eds) Fiocco, G. and Deepak, A., Hampton, Va., pp. 74-77, 1984.

Tachikawa, K., Jeandel, C., Vangriesheim, A., and Dupré, B.: Distribution of rare earth elements and neodymium isotopes in suspended particles of the tropical Atlantic Ocean (EUMELI site), Deep Sea Research I, 46, 733-756, 1999.

Tegen, I., Holrigl, P., Chin, M., Jacob, D., and Penner, J.: Contribution of different aerosol species to the global aerosol extinction optical thickness: Estimates from model results, J. Geophys. Res., 102, 23 895-23 915, 1997.

Turekian, K. K. and Wedepohl, K. H.: Distribution of the elements in some major units of the Earth's crust, Geol. Soc. Am. Bull., 72, 175-192, 1961. 